\title{
UNIVERSITYOF
}

FORWARD

THINKING

WESTMINSTER用

WestminsterResearch

http://www.westminster.ac.uk/westminsterresearch

Introduction: The Past, the Present and the Future of War and

Culture Studies

Kelly, D.

This is an Accepted Manuscript of an article published by Taylor \& Francis in the Journal of War and Culture Studies, 9 (3), 203-208, 2016. The definitive version is available online:

http://www.tandfonline.com/https://dx.doi.org/10.1080/17526272.2016.1190597.

The WestminsterResearch online digital archive at the University of Westminster aims to make the research output of the University available to a wider audience. Copyright and Moral Rights remain with the authors and/or copyright owners.

Whilst further distribution of specific materials from within this archive is forbidden, you may freely distribute the URL of WestminsterResearch: ((http://westminsterresearch.wmin.ac.uk/)).

In case of abuse or copyright appearing without permission e-mail repository@westminster.ac.uk 


\section{Introduction: The Past, the Present and the Future of War and Culture Studies}

Debra Kelly, University of Westminster

On the $25^{\text {th }}$ June 2015, the Twentieth Anniversary Conference of the Group for War and Culture Studies (GWACS) celebrated the past and present work of the last two decades, and looked forward to the future of the now well-established sub-discipline of war and culture studies. This was an important moment, shared with many long-established members of the GWACS and with scholars who have come more recently to its work. The five articles which make up the first of a special double issue to commemorate the conference are also representative of the approaches developed over the course of twenty years in the analysis of war and its impact on cultural production in many varied forms, and in varied temporal and geographical locations.

The Group for War and Culture Studies was founded in 1995 in the former School of Languages of the University of Westminster, and the history of the evolution of the GWACS has previously been covered in the first issue of the Journal of War and Culture Studies, published in 2008. It is fitting, however, to pay tribute again here to some of the GWACS founding members, firstly Hilary Footitt, former Head of the School of Languages at what was the Polytechnic of Central London and then the University of Westminster, and who gave the first keynote lecture at the anniversary conference. It is also an opportunity to honour Ethel Tolansky who was the original driving force behind the conception and creation of the Group, and whose work on Jean Cayrol and, for example, on authors in captivity, forms some of its important early contributions to the then non-existent field of 'war and culture studies'. Finally, Valerie Holman, Research Fellow to the GWACS in those early 
days, deserves further acknowledgement. Her energy, enthusiasm and belief in the work brought to fruition not only the first GWACS conference in 1996, but also its first co-edited publication: France at War in the $20^{\text {th }}$ century: propaganda, myth and metaphor (2000). Her 1997 final report on her two-year research fellowship made a number of essential points regarding the founding idea of 'war and culture studies':

I should like to congratulate the University of Westminster for its initiative in setting up the Group for War and Culture Studies. What appealed to me in the advertisement for the Research Fellowship was evidence of an open-mindedness that could envisage employing an art historian to complement and consolidate a research group composed largely of linguists and specialists in literature. What has been most rewarding for me personally is, I think, a reflection of the benefits gained by all members of the GWACS: participation in an academic research group that is not only interdisciplinary, but engages with areas of topical and universal concern. The launch of the GWACS was a bold and innovative initiative, and its first two years show how intellectual and practical concerns can prove mutually beneficial. To cite a single example: the round table on teaching about war, in addition to the anticipated involvement of academics from history and French Studies, drew written responses from the Army Museum and a television production company, and active participation from a psychologist and medical practitioner preparing doctors for working in war zones, and dealing with refugees from current international conflicts. That the GWACS has provided a forum in which issues confronting those actively engaged with people affected by war can be discussed with historians of conflict and 
specialists in the literature of memory and testimony, says much for the value of setting up such a research group. As a historian of art, I have found the dialogue with members of the School of Languages invaluable; it has provided a new perspective on cultural history and redirected my attention to the rhetoric which underlies much of what is written, said or depicted about war.

Valerie Holman also quickly saw that the GWACS's real potential lay as a national and an international forum - it became rapidly well-known and gained a national and international presence, and a reputation for introducing ideas and new research beyond the confines of an institutional framework. There was, therefore, immediately a large body of support for activities in the area of 'war and culture'. War and Culture Studies did not exist, and it is testimony to the way in which the 'group' functioned that today we can say war and studies is well-established on the academic discipline map. One example of this might be its inclusion in the overview of the development and future of French Studies in the UK, French Studies in and for the $21^{\text {st }}$ century (Worton and Lane, eds, 2011). As well as providing in this issue enduring testimony of the anniversary conference, it is time, therefore to consider the future of war and culture studies and that of the Group itself - now essentially less a 'group' than a loose national and international association of like-minded scholars across many disciplines - and to take the opportunity to take stock of the place of 'culture' in the continued study of war which is itself a constantly evolving phenomenon as several of the contributors to the conference noted.

More barriers than disciplinary ones have been broken down. In twenty years we have moved from a situation in which a set of male military historians could ask an eminent male historian of France (to his great 
indignation): 'who are these women who are messing about with war?', to one which enabled the recent observation of a contributors' panel at an event to celebrate the launch of a collective publication in 2014 , France in an era of global war, 1914-45: occupation, politics, empire and entanglements. At that event the panel was composed entirely of three dynamic female early career historians.

The open-minded of the GWACS, identified early on by Valerie Holman, has been its greatest attribute. Colleagues have also evoked its importance for young scholars who were made welcome there and many of whom gave their first papers at GWACS conferences (including two of the Journal of War and Culture Studies co-editors). This is one of its proudest achievements, and the academic impact of the GWACS is not to be underestimated. Less tangibly, but nonetheless true, it has been observed that the Group worked with 'something in the air', and it made things change. Indeed, one original aim of the journal was to provide a permanent home for those sometimes more ephemeral aspects of academic and intellectual life. This is therefore also the moment to thank our publishers, originally Intellect which allowed us to get our project off the ground and to establish itself, then Maney which worked hard over a couple of years or so on the further dissemination and reputation of the journal, and now Taylor and Francis which provides new networks and opportunities for the journal in the future.

Organised over one and half days, the conference's first keynote, as previously noted, was given by Hilary Footitt, much of whose recent work has focused on the importance of language during conflict, not least in her highly successful AHRC- funded 'Languages at War' project. The origins of the GWACS were then revisited with two papers on France, one on the First World War and one on the Second, with 
speakers who are again long-standing members of the Group and members of the editorial board of the JWACS, Alison Fell and Margaret Atack (whose work papers will be published in the second of this special double issue, 9.4). The second keynote was given by Bill Niven whose work came to our attention this time through the Journal of War and Culture Studies itself. His paper, as well as exemplifying his expertise and knowledge of German culture and the memory of war, was a fitting example of the development of war and culture studies through and with the journal. The titles of the parallel sessions reflected some of the current diverse interests of war and culture studies: enduring historical dimensions, facets of material culture, visual studies, science and culture, public/urban space and finally 'beyond text' into active, practical arenas of war (evoked so well all that time ago in Valerie Holman's early report), and these are covered in the articles which make up the two issues dedicated to the conference.

Hilary Footit's keynote, which provided the basis of the first article in this issue points to the future, but also allows a closing of the historical circle of the GWACS. In crucial ways, this article maps out a future for war and culture studies. Indeed as Footitt asks of the contemporary world: where is war? She firstly argues for a reconceptualization of the location of war as broader, in both spatial and temporal terms, than that of the nationstate with which it has been traditionally been associated. Above all, a powerful case is then made for the discipline of Translation Studies to become a leading contributor to war and culture studies. If war is to be understood spatially as transnational, this space is inevitably multilingual and filled with cultural products and cultural analysis from a very broad range of sources and reflections. The issue is, of course, one of how to access these forms of cultural production. Essentially, as in many other 
areas of modern language studies at the moment, the question is how to deal with the hyper-centrality of English. As for the Group's own history, we come full circle in more ways than one. When talking about the GWACS's origins, the importance of its genesis in the academic environment of Modern Languages - and specifically in French and Francophone literary, linguistic and cultural studies rather than, for example, in a department of History - is always to be emphasised as fundamental to its approaches and methodologies, to its 'sensibilities' and to its very essence. Finally, although Foottit is herself careful not to declare this a 'manifesto', indeed questioning the need for one, her argument makes a case for a conception of the transnational that has translation at its core, and it is a call to which the Journal of War and Culture Studies must rally in the future.

The issue then moves to two historically contextualised articles. Ian Germani's 'The Soldier's Death in French Culture: a Napoleonic Case Study' provides a welcome contribution to the journal's temporal remit which extends back to the beginnings of the European modern period. Using a variety of sources - reports, memoirs and academic paintings Germani charts the very different cultural attitudes prevalent in previous centuries towards the soldier's death and its representation. He notably contrasts it with those of the First World War, thereby providing a temporal and geographic link to the second article here. The death of the soldier and the representation of the body of the soldier have provided one of the most recurrent themes of the work of war and culture studies as contained in the Journal of War and Culture Studies, and this article makes a new contribution to that body of work.

Joëlle Prugnaud's 'Writers' Response to the Architectural Destructions of the Great War' retain us geographically in France, but to confront a very 
different sort of 'body', that of culture as represented in architecture and ravaged in war. Again, the First World War remains a touchstone for the development of work in war and culture studies, and this article continues that work. Prugnaud addresses the impact of architectural destruction on heritage culture through the particular prism of a literary approach, reading this destruction as evoked by a series of writers in order to express the collective sentiments of loss and mourning. She also links this analysis with research from other humanities disciplines while taking the opportunity to think about the literary treatment of architecture within a war and culture studies framework.

With Antonio Monegal's 'Picturing Absence: Photography in the Aftermath', a very different approach is taken to visual culture, and the article also moves forwards in time to the present and to the work of a series of contemporary photographers who grapple with the difficult aesthetic and ethical problems of representing not only something that has been destroyed, but that is now absent, together with the experiences of the anonymous and forgotten victims of war. At the same time, this article evokes a series of challenges that resonate with the case made by Hilary Footitt in the first article here concerning the blurring of war zones and sites of conflict no longer based on and in international confrontations between states, and in which the victim is more likely to be a civilian than a soldier (as analysed in Germani's earlier historical context). Monegal also identifies that the current conceptual framework of research and the tools available to us are "better attuned to the study and legacy of major historical conflicts"; just as changes in the conduct of war have brought about changes in its representation, further areas for future developments in the approaches and frameworks of war and culture studies are called for. 
The issue closes with a discipline new to the work of war and culture studies, that of polemobotany, a further example of new openings and new ways forward. James Wearn's 'Seeds of Change: Polemobotany in the Study of War and Culture' begins with the relatively neglected position of science in war and culture studies, and then goes on to discuss the place of polemobotany in particular. He reminds us of the ways in which plants and plant science have been closely associated with military activities of varied sorts throughout history, spanning both physical and psychological realms. Again with an eye to the future, Wearn ends with call for future research in war and culture studies to be truly multidisciplinary, echoing some of the voices in the first issue of Journal of War and Culture Studies. Some of that work is done; more needs to be done - sometimes with a development of the approaches now successfully embedded, sometimes differently - but the future of a now firmly established, but open-ended and still open-minded cultural reading of war seems secure. 